Article

\title{
Effects of Injection Timing on Combustion and Emission Performance of Dual-Fuel Diesel Engine under Low to Medium Load Conditions
}

\author{
Hua Zhou ${ }^{1,2}$, Hong-Wei Zhao ${ }^{1, *}$, Yu-Peng Huang ${ }^{3}$, Jian-Hui Wei ${ }^{3}$ and Yu-Hui Peng ${ }^{2,3, *(D)}$ \\ 1 School of Mechanical and Aerospace Engineering, Jilin University, Changchun 130022, China; \\ zhouhua@catarc.ac.cn \\ 2 China Automotive Technology and Research Center Co., Ltd., Tianjin 300300, China \\ 3 School of Mechanical Engineering and Automation, Fuzhou University, Fuzhou 350116, China; \\ N160220071@fzu.edu.cn (Y.-P.H.); N180220069@fzu.edu.cn (J.-H.W.) \\ * Correspondence: hwzhao@jlu.edu.cn (H.-W.Z.); pengyuhui@fzu.edu.cn (Y.-H.P.)
}

Received: 15 May 2019; Accepted: 13 June 2019; Published: 19 June 2019

\begin{abstract}
A throttle can be installed on the intake pipe of a natural gas (NG)/diesel dual-fuel engine to control the excess air ratio of the air-fuel mixture by adjusting the air intake. Building on a previously proposed NG/diesel dual-fuel supply strategy using the adjustment of excess air ratio, this work further studied the effects of different injection timing schemes on output power, fuel efficiency, and pollutant emissions of a dual-fuel engine under low to medium load conditions. In the experiment, the engine was operated at a speed of $1600 \mathrm{r} / \mathrm{min}$, under either low $(27.1 \mathrm{~N} \cdot \mathrm{m})$ or medium $(50.6 \mathrm{~N} \cdot \mathrm{m})$ loads, and the NG substitution rate was either $40 \%, 60 \%$, or $80 \%$. The effect of different injection timing schemes on the combustion performance of the engine under low to medium load conditions was studied based on in-cylinder pressure changes detected by a pressure sensor. Experimental results showed that under medium-speed low-load conditions and a NG substitution rate of $40 \%$, setting the diesel injection timing to $27{ }^{\circ} \mathrm{CA}$ BTDC increased the engine output power by $9.03 \%$, reduced the brake specific energy consumption (BSEC) by $13.33 \%$, and effectively reduced $\mathrm{CO}, \mathrm{CO}_{2}$, and $\mathrm{HC}$ emissions. Under medium-speed medium-load conditions with a NG substitution rate of $80 \%$, setting the diesel injection timing to $25^{\circ} \mathrm{CA}$ BTDC increased the engine output power by $14.62 \%$, reduced the $\mathrm{BSEC}$ by $11.73 \%$, and significantly reduced $\mathrm{CO}, \mathrm{CO}_{2}$, and $\mathrm{HC}$ emissions.
\end{abstract}

Keywords: excess air ratio; dual-fuel engine; natural gas; substitution rate; injection timing; bench test

\section{Introduction}

Natural gas (NG) is widely regarded as one of the most promising clean alternative fuels for internal combustion engines owing to its high hydrogen to carbon $(\mathrm{H} / \mathrm{C})$ ratio, high auto-ignition temperature, and affordable price. To date, research on NG/diesel dual-fuel engines has mainly focused on improving fuel economy and reducing pollutant emissions [1-3]. With the introduction of the GB20891-2014 standard in China, diesel engines of non-road mobile machinery will be required to comply with Grade III and Grade IV standards, which include more stringent pollutant emission requirements. Building upon on a previously proposed NG/diesel dual-fuel supply strategy based on adjustment of the excess air ratio, this study further examined the effect of diesel injection timing (DIT) on the performance of a NG/diesel dual-fuel engine under low to medium load conditions.

As indicated by existing studies, NG/diesel dual-fuel engines can significantly reduce soot and nitrogen oxide $\left(\mathrm{NO}_{\mathrm{x}}\right)$ emissions compared to conventional diesel engines, while remaining on par performance-wise, in terms of power output and fuel efficiency. However, under low to medium load conditions, combustion efficiency of the dual-fuel engine is low, and more carbon monoxide 
(CO) and unburned hydrocarbons (HCs) are emitted. In particular, under the low load condition, the small amount of fuel injected into the cylinder and abundant air supply results in an extremely lean air-fuel mixture in the cylinder. It is well recognized that a lean air-fuel mixture leads to slow unstable combustion, low combustion efficiencies, and high $\mathrm{CO}$ and $\mathrm{HC}$ emissions. Adjusting the degree of throttle opening to better control the excess air ratio is examined to be an effective way to attain an appropriate air-fuel ratio [4-7]. However, controlling the air intake flow by adjusting the throttle valve can increase pumping losses, leading to a decrease in volumetric efficiency [8]. In the previous study, the authors installed a throttle body on the original intake pipe of the diesel engine to control the air flow and to study the effects of different NG substitution rates (SR) on the performance of an engine working in the dual-fuel mode under low to medium load conditions [9]. Fuel supply strategies based on excess air and air/fuel ratio control effectively reduce $\mathrm{NO}_{\mathrm{x}}$ emissions and work well with SR reaching $40 \%$ under low-load conditions and $80 \%$ under medium-load conditions, which attained an acceptable improvement of the SR since no more than $30 \%$ of NG mass percentage is suggested by previous studies without throttle control at low load [10]. Nonetheless, this strategy is unable to reduce $\mathrm{CO}$ and $\mathrm{HC}$ emissions in the dual-fuel mode.

To solve the aforementioned problem, Yang et al. proposed advancing the DIT of a retrofitted NG/diesel dual-fuel engine when operating under low-load conditions and in this respect, achieved a high thermal efficiency and reduced CO and HC emissions [11]. Ref. [12] showed that DIT had a significant impact on the output power, maximum in-cylinder pressure, maximum combustion temperature, and maximum instantaneous heat release rate of diesel engines operating in the dual-fuel mode. Additionally, the usage of exhaust gas recirculation (EGR) and the air throttling strategy has been reported [10], and the study of optimal operation strategy for EGR rate was studied to run the engine with low emissions of $\mathrm{CO}_{2}$ and $\mathrm{HC}$ simultaneously under low load conditions [13]. Other studies have also described the effects of DIT and in-cylinder turbulence ratio on the in-cylinder combustion of engines working in the dual-fuel mode [14,15]. The work of Yousef et al. demonstrated that increasing the DIT could effectively reduce emissions of unburned methane and greenhouse gases when engines operate under low loads.

Under the requirement of minimum retrofit on the engine provided by the cooperative enterprise, our previous work examined that it was possible for the target engine working under low to medium load conditions to achieve a higher SR and to reduce nitrogen oxide $\left(\mathrm{NO}_{\mathrm{x}}\right)$ emissions by controlling the excess air ratio, without the support of EGR and turbocharger [9]. However, as the SR increases, increasing $\mathrm{CO}$ and $\mathrm{HC}$ emissions become salient. In this study as a successive work, an experiment was conducted to investigate the effect of DIT on the power output, fuel efficiency, and pollutant emissions of the target engine working under low to medium load conditions at NG/diesel dual-fuel mode. The experimental results demonstrated that proper DIT supported by a fuel supply strategy based on adjusting the excess air ratio can improve performance and reduce $\mathrm{NO}_{\mathrm{x}}, \mathrm{CO}, \mathrm{HC}$ and soot emissions. A high SR can be achieved for the dual-fuel engine working under low to medium load conditions. Moreover, the findings of this study provide a basis for formulating effective fuel supply strategies for the target engine working under low to medium load conditions at dual-fuel mode with a minimum retrofit cost.

\section{Design of Experiments}

\subsection{Dual-Fuel Supply System}

The non-road SL2110DKT-3 diesel engine tested in this study uses an electronic pump unit for fuel supply. The retrofitted NG/diesel dual-fuel supply system is shown in Figure 1. The dual-fuel supply system was obtained by adding an NG supply system to the original diesel supply system. Specifically, an NG mixer was installed in the intake manifold and multiple NG injection valves were mounted on the NG rail, which together enabled multi-point NG injection. The NG supply system consisted of a liquid NG storage tank, water bath vaporizer, NG filter, electromagnetic switch, pressure regulator, 
buffer tank, and NG rail. The buffer tank between the NG rail and flow meter could effectively stabilize the working pressure of the gas rail and the outlet pressure of the flow meter, thereby accurately controlling the quantity of NG injected into the cylinder. Injection valves mounted on the NG rail injected NG into the intake manifold via connected hoses. A throttle valve was installed in the general intake pipe to control the intake air volume of the engine, thus realizing precise control of the excess air ratio.

To reduce the effects of outlet pressure fluctuations of the NG injection valve on the NG injection volume, a secondary pressure-regulating valve and a secondary buffer tank were installed in front of the NG rail [16]. The NG injection valve queries the jet volume manifold absolute pressure (MAP) corresponding to the engine operating condition, followed by the injection time-pulse width MAP corresponding to the amount of air supply. The latter is based on the jet volume and air rail pressure. This setup controls the injection valve by adjusting the duty ratio. The NG supply system uses a normally open electronic throttle valve. The engine queries the target excess air ratio MAP according to the operating condition, and then queries the throttle opening degree MAP according to the engine speed and target excess air ratio.

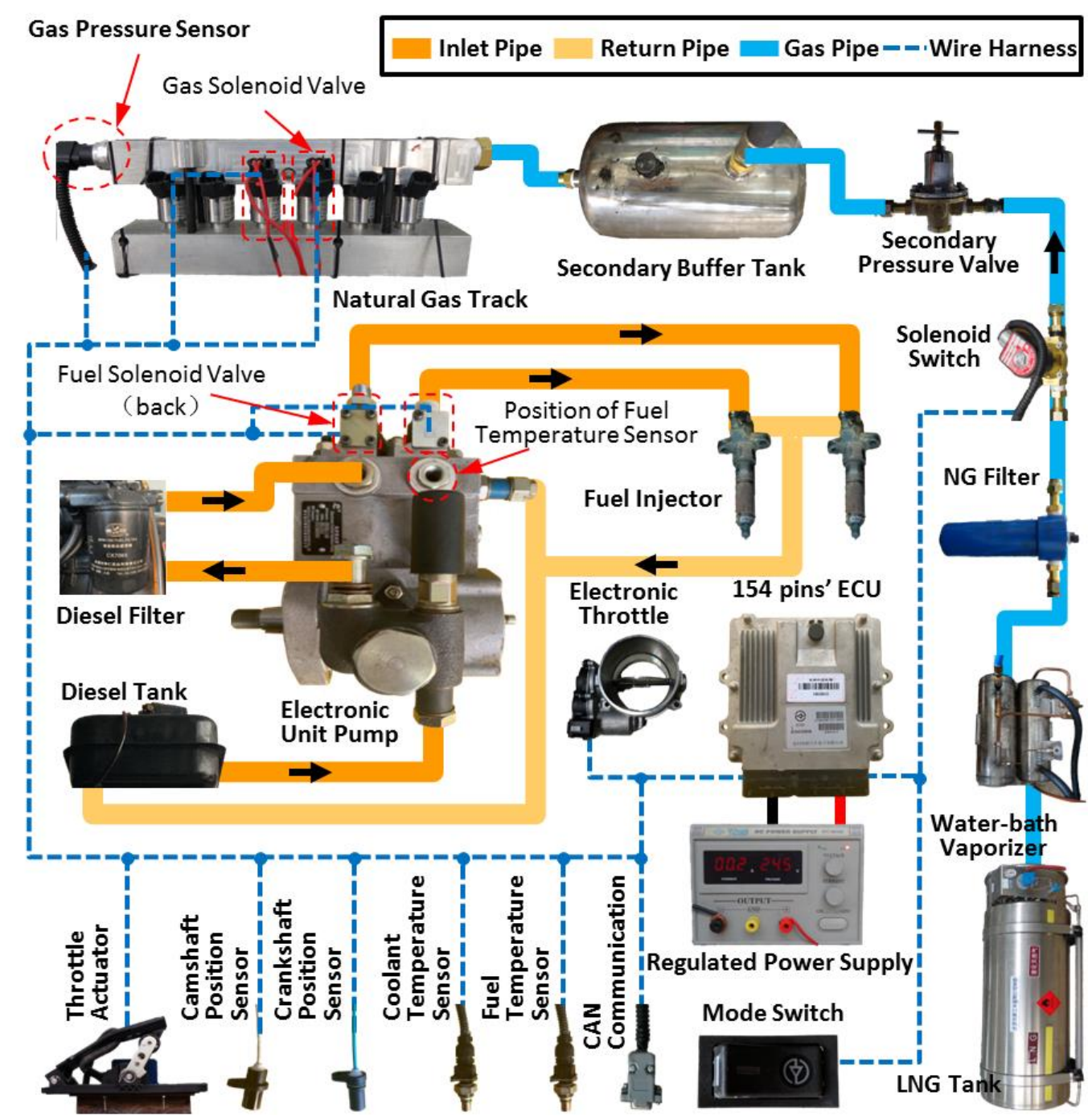

Figure 1. Dual-fuel supply system. 


\subsection{Test System}

The SL2110DKT-3 diesel engine is a four-stroke, inline water-cooled, naturally aspirated, and electronically controlled direct-injection two-cylinder diesel engine, mainly used in machines like tractors (T-type), harvesters, and construction machinery (K-type). Key technical parameters of the engine are listed in Table 1. Minimum fuel consumption of the engine went below $248.0 \mathrm{~g} / \mathrm{kW} \cdot \mathrm{h}$ and the maximum torque was $120.7 \mathrm{~N} \cdot \mathrm{m}$. With regards to emissions, the engine met the requirements of the Chinese Phase III standard for diesel engines of non-road mobile machinery.

Table 1. Engine specifications.

\begin{tabular}{cc}
\hline Engine Specifications & Value \\
\hline Rated power $(\mathrm{kW})$ & 25.7 \\
Rated speed $\left(\mathrm{r} \cdot \mathrm{min}^{-1}\right)$ & 2400 \\
Compression ratio & 17 \\
Displacement $(\mathrm{L})$ & 2.224 \\
Bore $\times$ Stroke $(\mathrm{mm})$ & $110 \times 117$ \\
Connecting rod length $(\mathrm{mm})$ & 185 \\
Inlet valve opening/closing $\left({ }^{\circ} \mathrm{CA}\right)$ & $12 \mathrm{BTDC} / 44 \mathrm{ABDC}$ \\
Exhaust valve opening/closing $\left({ }^{\circ} \mathrm{CA}\right)$ & $52 \mathrm{BBDC} / 12 \mathrm{ATDC}$ \\
Layout \& cylinders & Line 2 \\
Combustion chamber type & Direct injection $\omega$ type \\
Type of timing & $\mathrm{SEFI}$ \\
Injection interval & $180^{\circ} \mathrm{CA}$ \\
Injection pressure $(\mathrm{MPa})$ & $23 \sim 24$ \\
\hline
\end{tabular}

The framework of the test bench system for the dual-fuel engine is shown in Figure 2. The Toceil-OMFGO25 air flowmeter was installed in front of the throttle valve to measure real air flow. Diesel and NG were detected by a CMFD010 diesel mass flowmeter (Shanghai ToCeil Engine Testing Equipment, Shanghai, China) and an M250S flow meter (Alicat Scientific, Tucson, AZ, USA), respectively. The engine load and speed, pilot diesel injection timing, pilot diesel quantity, NG injection quantity, and throttle opening were controlled with the assistance of the ECKA V2 engine calibration software and a DW63 engine dynamometer. Additionally, a high-temperature pressure sensor (6052C, Kistler, Winterthur, Switzerland) was fitted inside the cylinder head of the first cylinder to obtain the in-cylinder pressure. Smoke and gas emissions of $\mathrm{CO}$, carbon dioxide $\left(\mathrm{CO}_{2}\right), \mathrm{HCs}$, and $\mathrm{NO}_{\mathrm{x}}$ were measured using a smoke meter (FTY-100 Opacimeter, Foshan Analytical Instruments, Foshan, China) and an exhaust gas analyzer (Infralyt ELD V347, SAXON Junkalor GmbH, Dessau-Roßlau, Germany), respectively. Specifications and precision of the main instruments used in the study are listed in Table 2. 


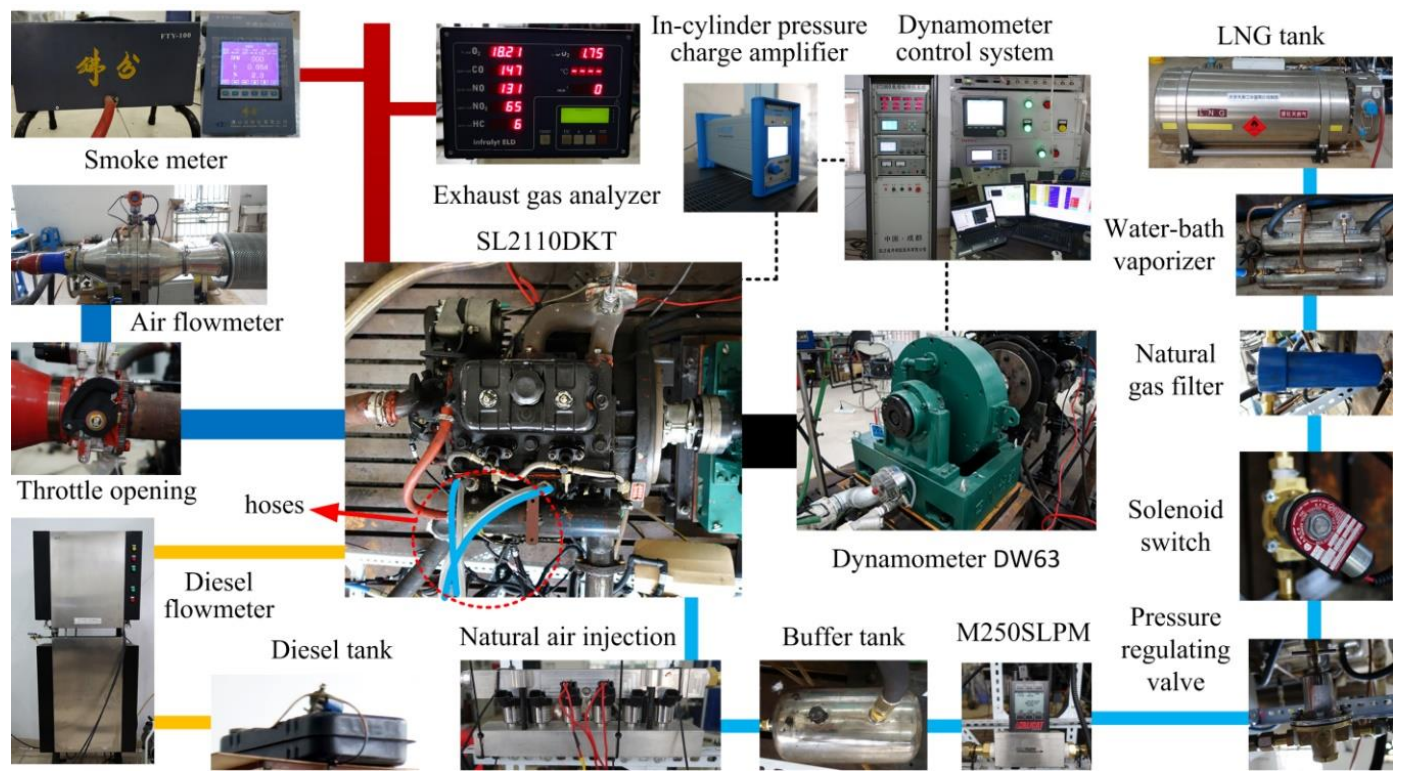

Figure 2. Dual-fuel engine test bench system.

Table 2. Main instruments used in this study.

\begin{tabular}{llc}
\hline \multicolumn{1}{c}{ Item } & \multicolumn{1}{c}{ Specification } & Precision \\
\hline \multirow{2}{*}{ Dynamometer } & Torque $\mathrm{N} \cdot \mathrm{m}$ & $\pm 0.4 \%$ F.s \\
\cline { 2 - 3 } & Rotation Speed $\mathrm{rpm}$ & $0.1 \% \pm 1$ \\
\hline Diesel flowmeter & Fuel mass flow $\mathrm{kg} / \mathrm{h}$ & $\pm 0.12 \%$ \\
\hline Air flowmeter & Fuel mass flow $\mathrm{kg} / \mathrm{h}$ & $\pm 0.5 \%$ \\
\hline Natural gas flowmeter & Volumetric flow rate SLPM & $\pm 0.8 \%$ \\
\hline Pressure sensor & In-cylinder pressure bar & $\leq \pm 0.5 \mathrm{bar}$ \\
\hline \multirow{3}{*}{ Exhaust gas analyzer } & Volume percent of CO ppm & $10 \mathrm{ppm}$ \\
\cline { 2 - 3 } & Volume percent of $\mathrm{CO}_{2} \mathrm{ppm}$ & $\pm 0.4 \%$ \\
\cline { 2 - 3 } & Volume percent of $\mathrm{HC} \mathrm{ppm}$ & $\pm 10 \mathrm{ppm}$ \\
\cline { 2 - 3 } & Volume percent of $\mathrm{NO}_{\mathrm{ppm}}$ & $\pm 12 \mathrm{ppm}$ \\
\cline { 2 - 3 } & Volume percent of $\mathrm{NO}_{2} \mathrm{ppm}$ & $\pm 5 \mathrm{ppm}$ \\
\hline Smoke meter & Smoke opacity $\%$ & \pm 0.1 \\
\hline
\end{tabular}

All instruments were calibrated before the experiment, and the measurement range and accuracy of each measuring instrument were found to meet requirements. Standard gases $\left(\mathrm{C}_{3} \mathrm{H}_{8}, \mathrm{NO}, \mathrm{CO}\right.$, and $\mathrm{CO}_{2}$ ) were applied to calibrate the exhaust gas analyzer and the opacimeter was calibrated using standard test glass sheets with different degrees of opacity $(10 \%, 30 \%, 50 \%$, etc.). The instantaneous fuel consumption meter, air flow meter, NG flow meter, and pressure sensor were regularly calibrated by the manufacturer.

\subsection{Test Procedure}

The fuel supply strategy based on excess air ratio control was previously described in detail [9]. In the pure diesel mode, low $(27.1 \mathrm{~N} \cdot \mathrm{m})$ and medium $(50.6 \mathrm{~N} \cdot \mathrm{m})$ loads at the target speed were selected as the target operating conditions. The target speed was selected as $1600 \mathrm{r} / \mathrm{min}$ according to GB20891-2014 [17]. The rated torque for a speed of $1600 \mathrm{r} / \mathrm{min}$ is $120 \mathrm{~N} \cdot \mathrm{m}$, therefore, torque values of $27.1 \mathrm{Nm}$ and $50.6 \mathrm{Nm}$ represent the low load (22.5\%) and medium load (42.2\%) conditions of the engine. To study the effect of DIT on the performance of the NG/diesel dual-fuel engine under low 
to medium load conditions, the DIT was adjusted by step increases or decreases of $2{ }^{\circ} \mathrm{CA}$. The pilot diesel quantity $\left(m_{d 2}\right)$, target air supply quantity $\left(m_{\text {air }}\right)$, and target NG injection quantity $\left(m_{\mathrm{NG}}\right)$ for each experimental case is shown in Table 3 , where $m_{d 1}$ is the diesel injection quantity of the engine working in the pure diesel mode and $R$ is the NG substitution rate, defined as

$$
R=\frac{m_{d 1}-m_{d 2}}{m_{d 1}} \times 100 \%
$$

Table 3. Parameter values used in dual-fuel experiments.

\begin{tabular}{|c|c|c|c|c|c|c|c|}
\hline $\begin{array}{l}\text { Experiment } \\
\text { Case }\end{array}$ & $\begin{array}{c}m_{d 1} \\
\text { (Mg/Cylinder } \\
\text { Cycle) }\end{array}$ & $R \%$ & $\begin{array}{c}m_{d 2} \\
\text { (Mg/Cylinder } \\
\text { Cycle) }\end{array}$ & $\phi_{\mathrm{a}}$ & $\begin{array}{c}m_{\text {air }} \\
\text { (Mg/Cylinder } \\
\text { Cycle) }\end{array}$ & $\begin{array}{c}m_{\mathrm{NG}} \\
\text { (Mg/Cylinder } \\
\text { Cycle) }\end{array}$ & $\begin{array}{c}\text { Injection } \\
\text { Timing } \\
\left({ }^{\circ} \mathrm{CA} \text { BTDC) }\right.\end{array}$ \\
\hline $1600 \mathrm{r} / \mathrm{min}$ & \multirow{2}{*}{19.69} & 40 & 11.81 & \multirow{2}{*}{3.25} & 933.58 & 6.80 & \multirow{4}{*}{$\begin{array}{c}15,17,19,21,23, \\
25,27\end{array}$} \\
\hline$(4.54 \mathrm{~kW})$ & & 60 & 7.88 & & 936.80 & 10.09 & \\
\hline \multirow{2}{*}{$\begin{array}{c}1600 \mathrm{r} / \mathrm{min} \\
(8.48 \mathrm{~kW})\end{array}$} & \multirow{2}{*}{31.04} & 60 & 12.42 & & 1027.13 & 15.92 & \\
\hline & & 80 & 6.21 & 2.26 & 1030.67 & 21.11 & \\
\hline
\end{tabular}

The engine was fueled with commercial $0 \#$ diesel and natural gas obtained from a local filling station in Fuzhou city. The detailed specifications of the two fuels are listed in Table 4.

Table 4. Physico-chemical properties of fuel and natural gas.

\begin{tabular}{cccc}
\hline Item & Unit & Diesel & Natural Gas \\
\hline Chemical formula & & $\mathrm{C}_{\mathrm{n}} \mathrm{H}_{\mathrm{m}}$ & $\mathrm{CH}_{4}$ \\
Component quality & $\mathrm{g}_{\mathrm{C}} / \mathrm{kg}$ & 0.847 & 0.750 \\
Molecular mass & $\mathrm{g} / \mathrm{kg}$ & 0.126 & 0.250 \\
Stoichiometric & & $180 \sim 200$ & 16 \\
Lower heat value & $\mathrm{MJ} / \mathrm{kg}$ & 42.5 & 17.4 \\
Heat value at $\phi_{\mathrm{a}}=1$ & $\mathrm{~kJ} / \mathrm{m}^{3}$ & 3750 & 50.5 \\
\hline
\end{tabular}

During bench tests, the dynamometer was used at a constant speed of $1600 \mathrm{r} / \mathrm{min}$ and the engine was preheated in the pure diesel mode. The engine was deemed to have reached a stable operating state when the coolant temperature reached $60{ }^{\circ} \mathrm{C}$, fluctuations in engine speed were less than $2 \mathrm{r} / \mathrm{min}$, and torque fluctuations were less than $0.1 \mathrm{Nm}$. All tests were performed when the coolant temperature and lubricant temperature were about $85^{\circ} \mathrm{C}$ and $75^{\circ} \mathrm{C}$, respectively. The engine output power, BSEC, and pollutant emissions were analyzed under different operating conditions. At an engine speed of $1600 \mathrm{r} / \mathrm{min}$, the DIT was 17 degrees before top dead centre ( ${ }^{\circ} \mathrm{CA}$ BTDC) and the NG injection timing was $300{ }^{\circ} \mathrm{CA}$ BTDC.

\section{Analysis of Test Results}

\subsection{Power Performance}

The target power of the engine, working at pure diesel mode, at $1600 \mathrm{r} / \mathrm{min}$ and $22.5 \%$ load was $4.54 \mathrm{~kW}$. Figure 3 shows the output power of the engine working in the dual-fuel mode under low load (22.5\%) for different DITs and SRs. Under the medium-speed (1600 r/min) low-load condition, with either $40 \%$ or $60 \%$ SR, the output power increased with advancing DIT in the mass. The cylinder pressure traces (see in Figure 4) reveals that advancing DIT generally helps to improve in-cylinder pressure. When DIT has advanced from $17^{\circ} \mathrm{CA} \mathrm{BTDC}$ to $27^{\circ} \mathrm{CA} \mathrm{BTDC}$, the ignition delay is prolonged and combustion phasing is retarded, which may help to form more fuel-air mixture before the start of combustion, which favors the formation of the ignition kernel [18]. However, with the increase of SR combustion, phasing is retarded because of the smaller pilot diesel injection. In this case, most of the NG-air mixture was burned during the expansion stroke, the peak pressure decreased (showed in 
Figure $4 \mathrm{~b}$ ) and the engine power output fell below the red dotted line displayed in Figure 3. Therefore, to achieve $40 \%$ SR under the medium-speed low-load condition it is feasible to advance DIT to $27^{\circ} \mathrm{CA}$ BTDC and therefore the output power of the engine rose by $9.03 \%$.

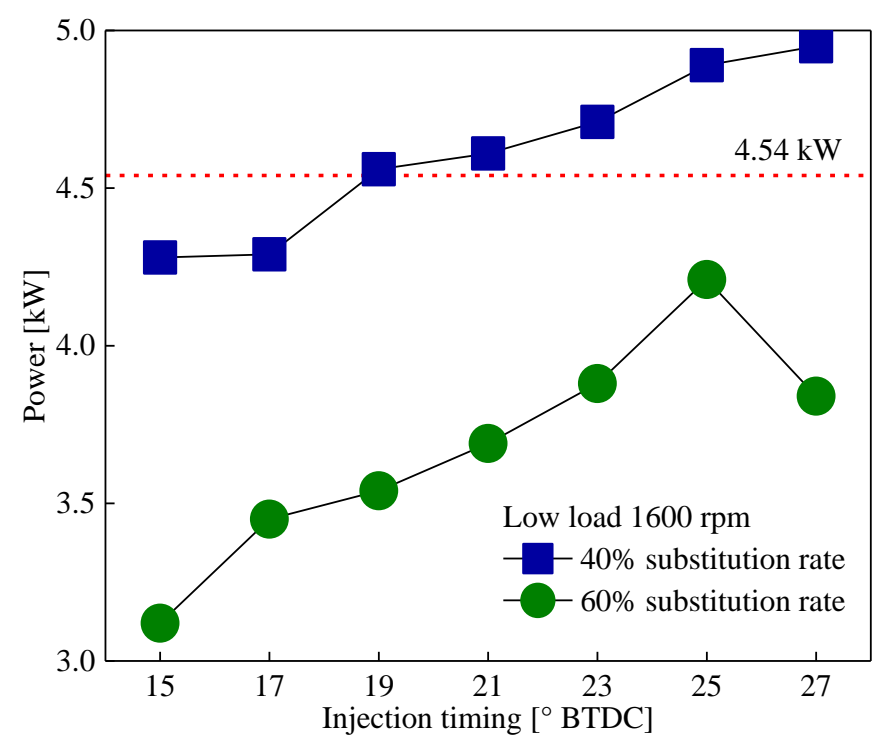

Figure 3. Comparison of power outputs with different diesel injection timings at low load.

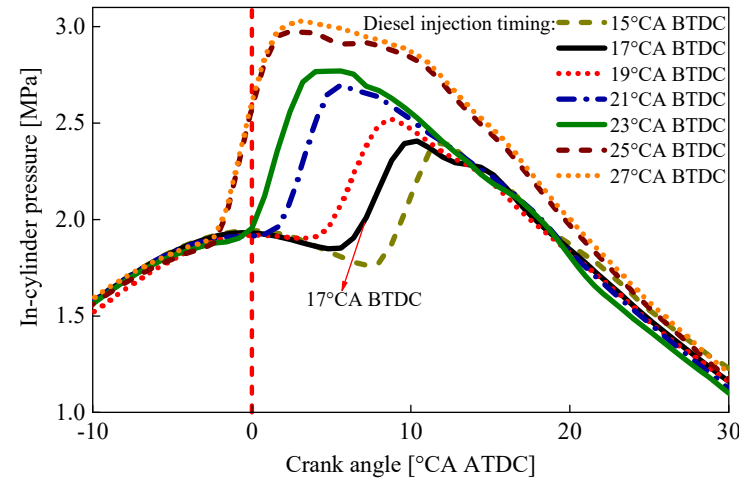

(a)

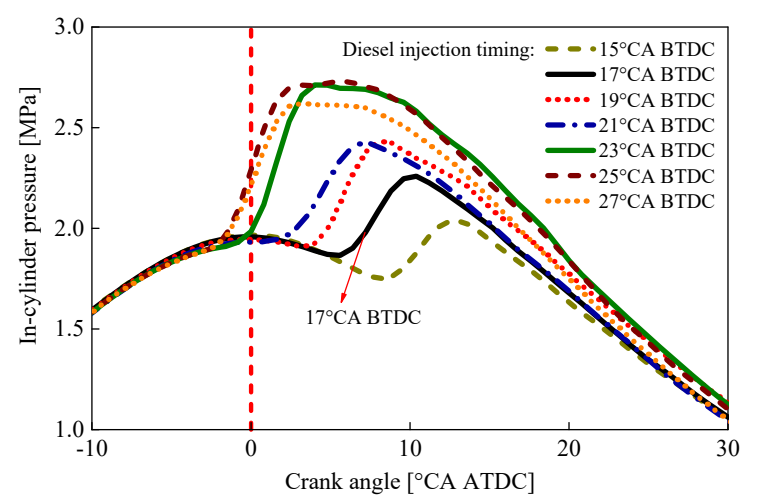

(b)

Figure 4. Comparison of in-cylinder pressure with different diesel injection timings at low load. (a) Cylinder pressure traces under different diesel injection timing under $22.5 \%$ load and $40 \%$ substitution rate. (b) Cylinder pressure traces under different diesel injection timing under $22.5 \%$ load and $60 \%$ substation rate.

The target output power of the engine at medium speed and medium load was $8.48 \mathrm{~kW}$. Figures 5 and 6 show the output power values and in-cylinder pressure of the engine working in the dual-fuel mode with medium load obtained for different DITs, respectively. The output power increased under both $60 \%$ and $80 \%$ SRs with advancing DIT. Compared to the low load condition, more pilot diesel was provided at medium load, and the negative influence of prolonged combustion phasing caused by insufficient pilot diesel was suppressed. Therefore, as high as $80 \%$ SR can be accepted at medium speed and medium load, increasing output power by $14.62 \%$ as the DIT advanced to $25^{\circ} \mathrm{CA}$ BTDC. It should be noted that when advancing DIT to $27^{\circ} \mathrm{CA}$ BTDC under $80 \% \mathrm{SR}$, the output power had an abrupt drop as shown in Figure 5. Since the retrofitted NG/diesel dual-fuel engine is a naturally aspirated engine, the combustible NG-air mixture forms during the intake stroke, and temperature in the combustion chamber gradually drops as the SR increases. If advancing DIT breaks through the critical point, the temperature of the large volume of combustible mixture formed during the ignition 
delay period will be lower, resulting in lower combustion reaction and the peak pressure drops (see Figure $6 b)$.

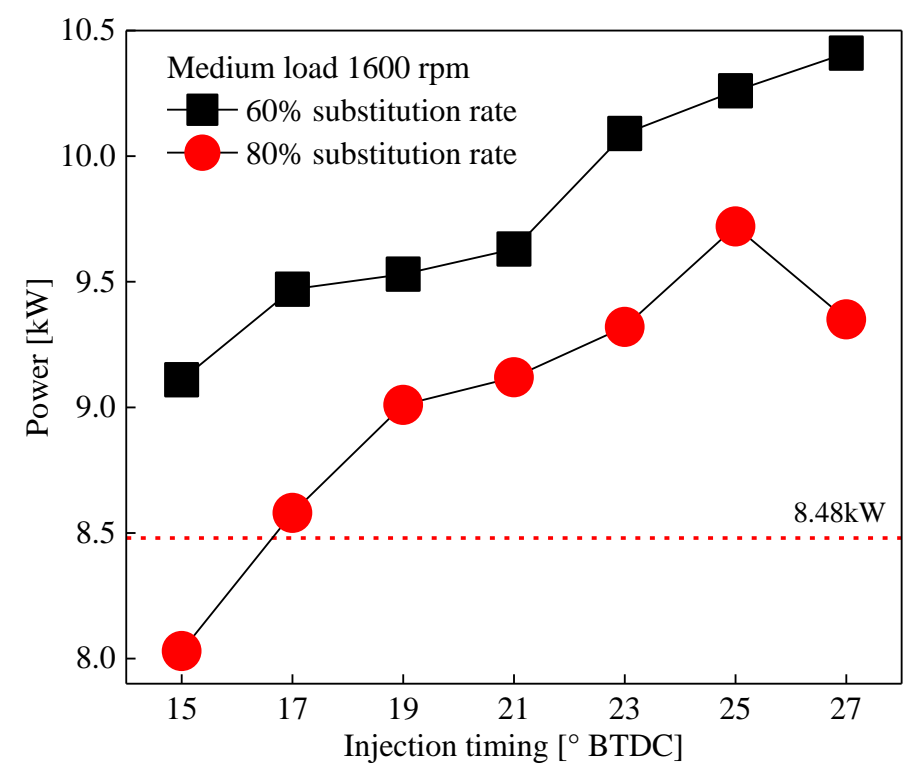

Figure 5. Comparison of power outputs with different diesel injection timings under medium load.

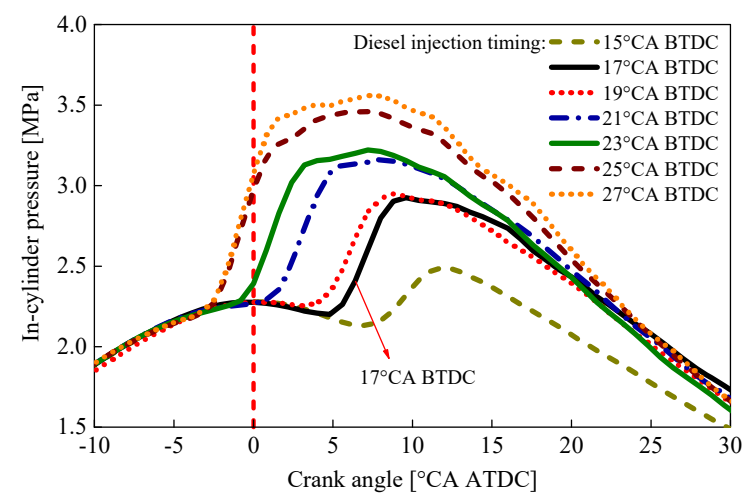

(a)

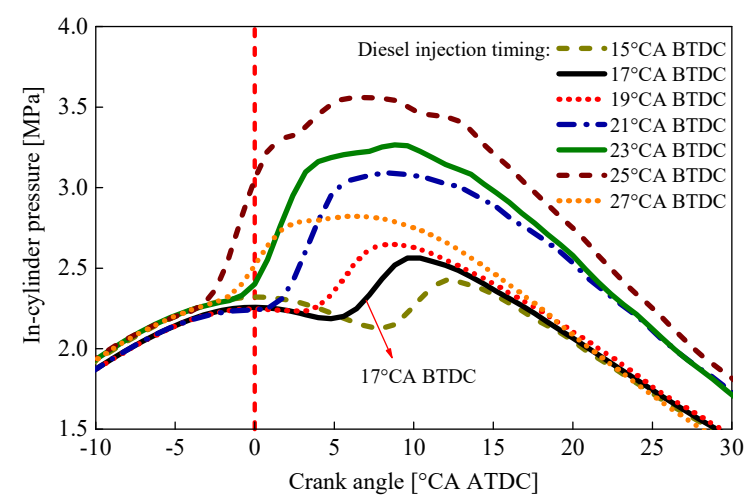

(b)

Figure 6. Comparison of in-cylinder pressure with different diesel injection timings. (a) Cylinder pressure traces under different diesel injection timing under $42.2 \%$ load and $60 \%$ substitution rate. (b) Cylinder pressure traces under different diesel injection timing under $42.2 \%$ load and $80 \%$ substitution rate.

In general, advancing the DIT can effectively increase engine output power in the dual-fuel mode. Under medium-speed low-load operating conditions with a 40\% SR, advancing the DIT can effectively avoid the decline in output power often experienced by diesel engines working in the dual-fuel mode under low load conditions. Under medium-speed medium-load operating conditions, advancing the DIT within a reasonable range can effectively increase engine output power even if the SR is as high as $80 \%$.

\subsection{Brake Specific Energy Consumption}

The indicator of brake specific energy consumption (BSEC) is calculated as the reciprocal of the fuel conversion efficiency in units of MJ/kWh. The varying BSEC for various operating conditions at low load and medium load are shown in Figures 7 and 8, respectively. Under the low-load condition and $40 \%$ SR, the engine BSEC dropped to $16.34 \mathrm{MJ} / \mathrm{kWh}$ when the DIT shifted to $27^{\circ} \mathrm{CA}$ BTDC, which 
was $13.33 \%$ lower than the BSEC value measured in the pure diesel mode with the DIT of $17^{\circ} \mathrm{CA}$ BTDC [9]. Similarly, the BSEC reduced by $11.73 \%$ when the DIT increased to $25^{\circ} \mathrm{CA}$ BTDC under the medium-load condition and $80 \%$ SR compared to the corresponding BSEC value in the pure diesel working condition. Lower BSEC implies an efficiency promotion in the dual-fuel mode due to the prolonged ignition delay and higher flame velocity owing to the DIT advancing [14].

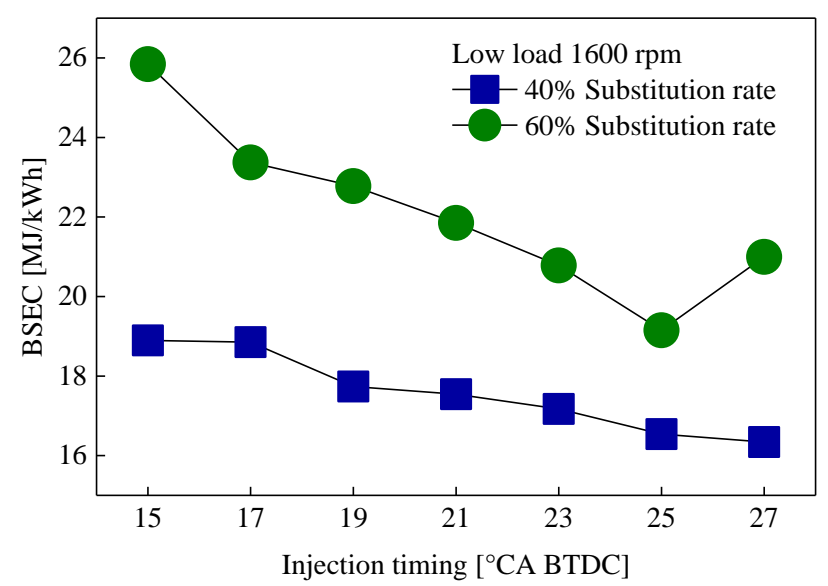

Figure 7. Comparison of BSEC with different diesel injection timings under low load.

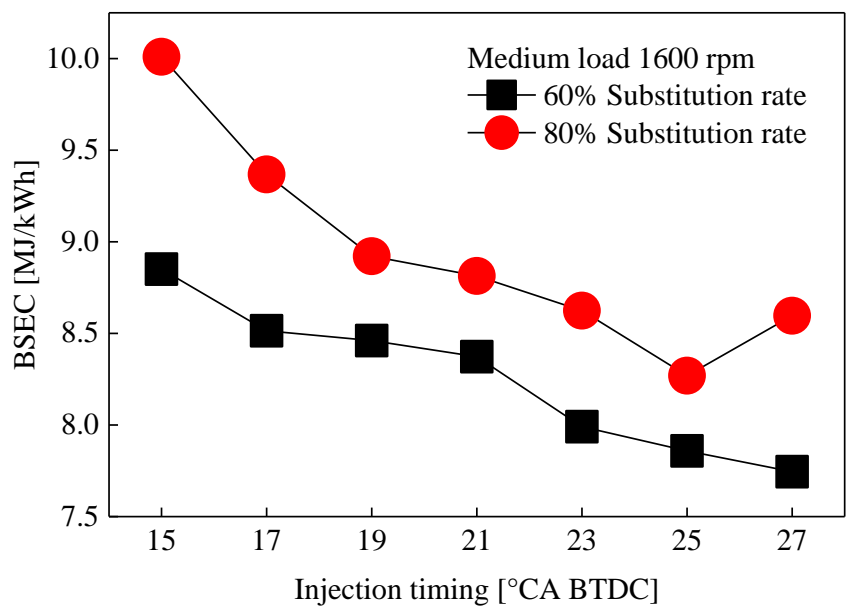

Figure 8. Comparison of BSEC for different diesel injection timings under medium load.

\subsection{Pollutant Emissions}

To compare pollutant emission levels under different operating conditions, the volume concentrations of each discharged pollutant were converted to specific emissions according to the provisions of GB20891-2014. The engine specific emissions are mainly determined by the volume of exhaust pollutant generated and the engine output power. Under the same target operating conditions, as well as the same quantity of injected NG and pilot diesel, variation of exhaust pollutants was mainly owing to the variable power output under different DITs. As a critical parameter affecting in-cylinder combustion, the DIT had a large impact on the formation of the NG-air-diesel mixture and the premixed combustion process. The premixed combustion process affects the quality of diffusion combustion, which in turn affects the chemical reactions that take place in the cylinder. The quality of in-cylinder combustion not only affects the amount of each pollutant in the exhaust, but also the output power of the engine.

Figure 9 shows specific $\mathrm{CO}$ emissions of the engine working in the dual-fuel mode obtained for different DITs. Under the low-load and medium load condition, the specific $\mathrm{CO}$ emissions gradually 
decreased in the general trend as the DIT increased. It is well recognized that three key factors are involved in the formation of $\mathrm{CO}$, comprising of a sudden temperature drop of the combustible mixture in the cylinder, a sudden lack of oxidant and the too short reaction time of the combustible mixture [19]. Under the low-load condition and $40 \%$ SR, CO emissions decreased by $18 \%$ when the DIT increased from $17{ }^{\circ} \mathrm{CA}$ BDTC to $27^{\circ} \mathrm{CA}$ BTDC. The improvement in specific CO emissions was mainly due to a reduction of incomplete combustion zones in the engine $[19,20]$. The improvement in engine in-cylinder combustion led to an increase in engine output power, which in turn led to a decrease in $\mathrm{CO}$ emissions. Under the low-load condition and $60 \% \mathrm{SR}$, the $\mathrm{CO}$ emissions were lower, compared to the $40 \%$ SR, when the DIT was $23^{\circ} \mathrm{CA} \mathrm{BTDC}, 25^{\circ} \mathrm{CA}$ BTDC, and $27^{\circ} \mathrm{CA}$ BTDC.

It should be noted that the engine output power cannot reach the target of $4.54 \mathrm{~kW}$ under the low-load condition with a $60 \%$ SR. Therefore, even though slightly lower pollutant emission levels can be achieved under the low-load condition and 60\% SR, DIT-based optimization cannot be used as the fuel supply strategy because the engine output power cannot meet the target requirement at this $S R$. For medium load conditions with an $80 \%$ SR, in-cylinder combustion occurs close to the homogeneous charge compression ignition, which reduces the possibility of the in-cylinder combustible mixture being too rich or too lean. When the DIT is properly advanced $\left(25^{\circ} \mathrm{CA}\right.$ BTDC, $\left.27^{\circ} \mathrm{CA} \mathrm{BTDC}\right)$, specific $\mathrm{CO}$ emissions can be improved and a relatively low level of emissions can be maintained.

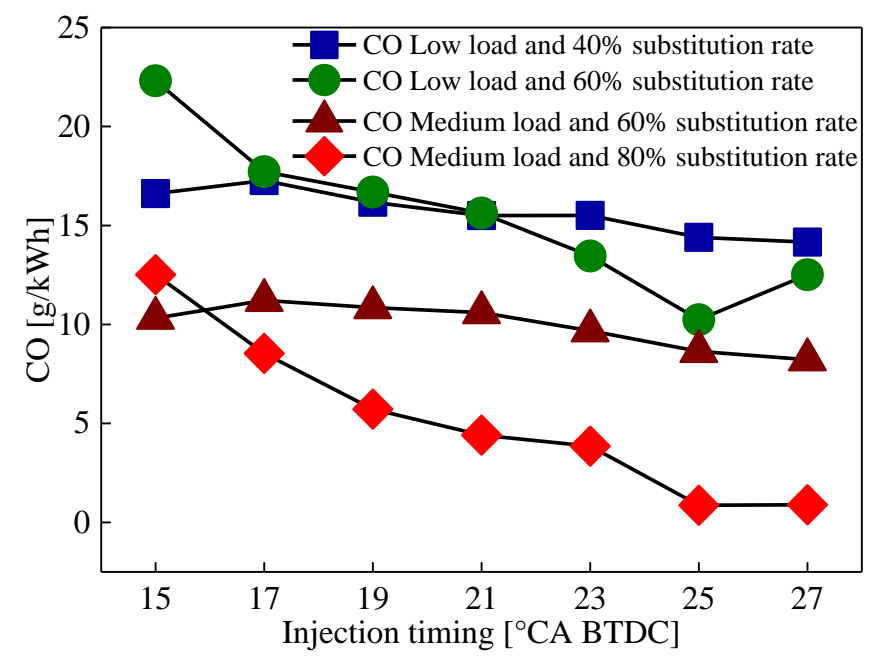

Figure 9. Comparison of $\mathrm{CO}$ emissions with different diesel injection timings.

The generation of $\mathrm{HC}$ emissions were similar to $\mathrm{CO}$ generation [20-23]. Figure 10 shows the specific HC emissions of the engine working in the dual-fuel mode, obtained for different DITs. Under the low-load and medium-load condition, specific HC emissions gradually decreased as the DIT increased in the overall trend. With advancing DIT, more premixed natural gas-air and diesel mixture forms before the start of combustion, which shifts the combustion phasing towards the TDC and the in-cylinder temperature is increased during the combustion phasing. Then, HC emission is decreased inevitably. Under the medium-speed low-load condition and $40 \%$ SR, specific HC emissions were maintained at around $6.10 \mathrm{~g} / \mathrm{kWh}$. Also, specific HC emissions under these conditions were significantly lower than those produced with a $60 \% \mathrm{SR}$, due to the more unburned methane which resulted from the low combustion temperature. For the medium-load condition with $80 \% \mathrm{SR}$, when the DIT was advanced to $19^{\circ} \mathrm{CA}$ BTDC or later, the average specific HC emissions were $2.37 \mathrm{~g} / \mathrm{kWh}$, which was on par with those produced by the $60 \% \mathrm{SR}$. Though more natural gas is fueled, high combustion temperature and a combustion reaction can make the natural gas burn well, and the influence of unburned methane is very slight. 


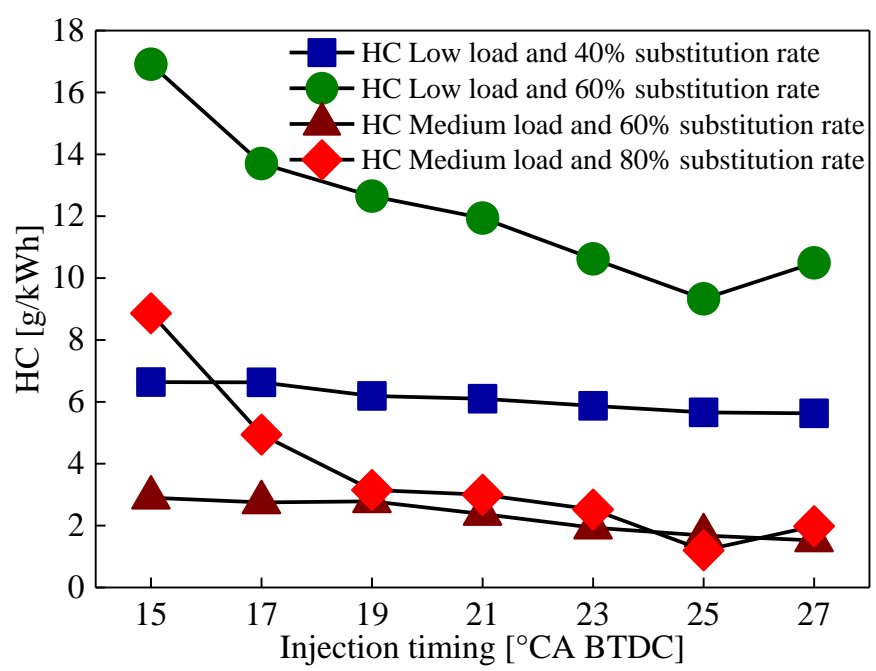

Figure 10. Comparison of hydrocarbons emissions with different diesel injection timings.

Figure 11 shows the $\mathrm{NO}_{\mathrm{x}}$ emission of the engine working in the dual-fuel mode obtained for different DITs. Under the low-load and medium load condition, specific $\mathrm{NO}_{\mathrm{x}}$ emissions gradually increased with increasing DIT. It is generally believed that the formation of $\mathrm{NO}_{\mathrm{x}}$ is favored by the abundant oxygen level, the highest temperature in the cylinder resulting from combustion, and the long reaction time. If the DIT advances, the rapid combustion period starts earlier; consequently, pressure increases at a higher rate during the rapid combustion period, leading to a higher combustion temperature, which decreases the soot emissions (see Figure 12), especially for the relative high SR cases. Since the rapid combustion period ends earlier, the post-combustion period and the continual combustion period are extended, leaving more time for the $\mathrm{NO}_{x}$-generation reactions-hence, increased specific $\mathrm{NO}_{x}$ emissions. Similar findings have also been explored in previous research [24-28]. On the other hand, the in-cylinder combustion temperature decreased as the SR increased and injecting more $\mathrm{NG}$ effectively reduced specific $\mathrm{NO}_{\mathrm{x}}$ emissions. Therefore, to control specific $\mathrm{NO}_{\mathrm{x}}$ emissions, it is not advisable to advance the DIT too much. The DIT can be decreased moderately as long as the output power meets the target requirement. This approach can help achieve a good balance between $\mathrm{CO}, \mathrm{HC}$, and $\mathrm{NO}_{\mathrm{x}}$ emissions. As far as soot emission was concerned, under the same speed and load condition with the same DIT, the soot increased with the increase of SR. This is likely a result of the lower initial charge temperatures, which also leads to relatively higher soot levels [29].

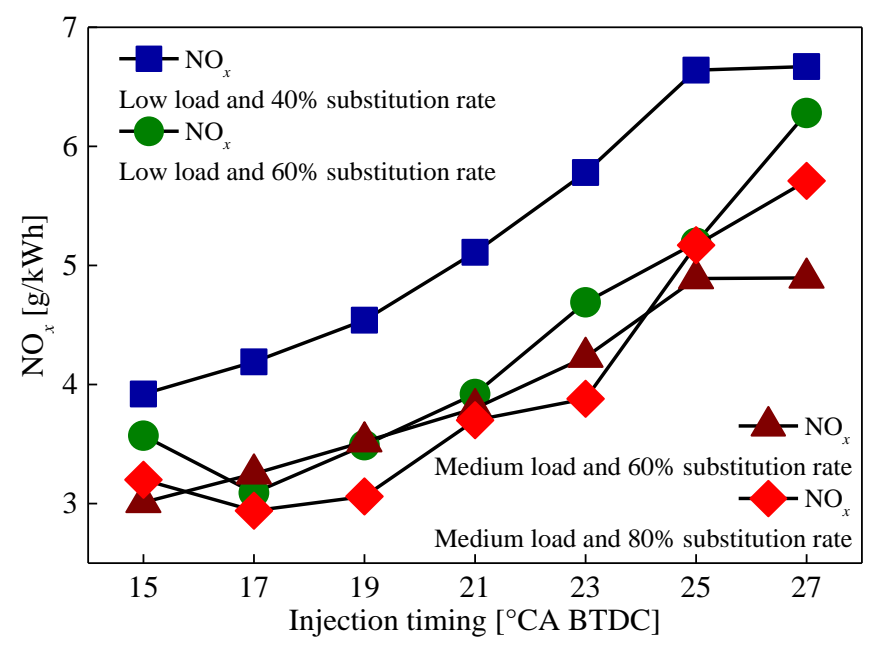

Figure 11. Comparison of $\mathrm{NO}_{x}$ emissions with different diesel injection timings. 


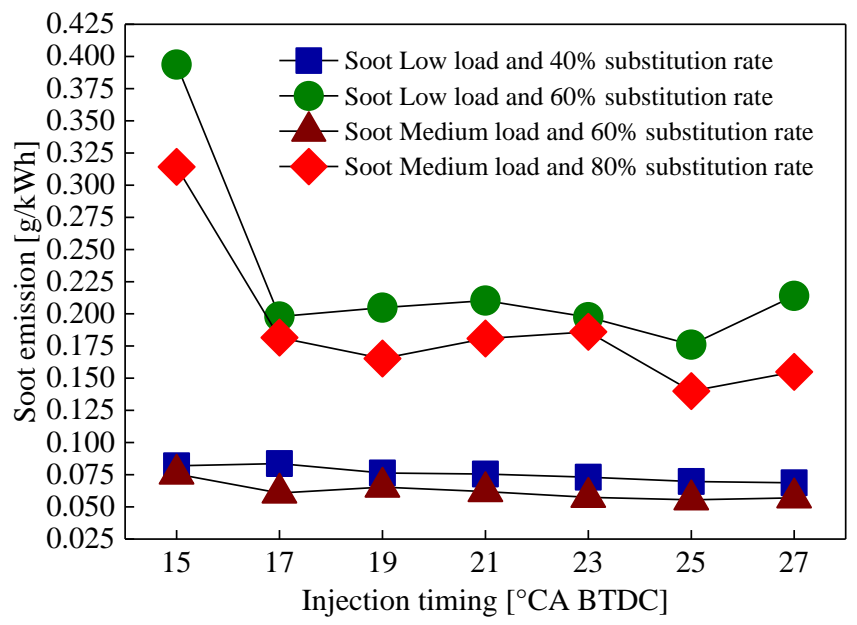

Figure 12. Comparison of soot emissions with different diesel injection timings.

\section{Conclusions}

For the target engine without EGR and turbocharger, working in NG/diesel dual-fuel mode with excess air ratio control, advancing the DIT under medium-speed low-load operating conditions could increase the output power to meet the target requirement of $4.54 \mathrm{~kW}$ achieving $40 \% \mathrm{SR}$. Under medium-speed medium-load conditions, it was feasible to increase the output power when a relatively high $(80 \%)$ SR was obtained. Meanwhile, advancing the DIT could effectively improve fuel economy. Under medium-speed low-load conditions, along with a 40\% SR, the engine BSEC could be effectively improved by $13.33 \%$ increasing the DIT to $27^{\circ} \mathrm{CA}$ BTDC. Under medium-speed medium-load conditions with an $80 \%$ SR and DIT $\leq 25^{\circ} \mathrm{CA}$ BTDC, the engine BSEC decreased with increasing DIT, which improved fuel efficiency. Moreover, under the medium-speed low-load conditions and $40 \%$ $\mathrm{SR}$, specific $\mathrm{CO}, \mathrm{CO}_{2}, \mathrm{HC}$ and soot emissions were effectively reduced as the DIT increased, however, specific $\mathrm{NO}_{x}$ emissions increased. Under the medium-speed medium-load condition with an $80 \%$ $\mathrm{SR}$, specific $\mathrm{CO}, \mathrm{CO}_{2}, \mathrm{HC}$ and soot emissions were also effectively reduced as the DIT increased but accompanied by a dramatic increase in specific $\mathrm{NO}_{x}$ emissions. Therefore, advancing DIT before the critical point might be an advisable way to balance the requirements of power output, fuel efficiency and emissions.

Author Contributions: Conceptualization, Y.-H.P.; data curation, Y.-P.H. and J.-H.W.; funding acquisition, Y.-H.P.; investigation, H.Z. and Y.-P.H.; methodology, H.Z., H.-W.Z. and Y.-H.P.; project administration, H.-W.Z. and Y.-H.P.; supervision, H.-W.Z.; writing-original draft, H.Z. and Y.-H.P.

Funding: This research was supported by the Fujian Provincial Research Program of Industry-University Partnership (grant No. 2017H6007).

Conflicts of Interest: The authors declare no conflict of interest.

\section{References}

1. Nithyanandan, K.; Zhang, J.; Li, Y.; Meng, X.; Donahue, R.; Lee, C.F.; Dou, H. Diesel-like efficiency using compressed natural gas/diesel dual-fuel combustion. J. Energy Resour. Technol. 2016, 138, 052201. [CrossRef]

2. Carlucci, A.; deRisi, A.; Laforgia, D.; Naccarato, F. Experimental investigation and combustion analysis of a direct injection dual-fuel diesel-natural gas engine. Energy 2008, 33, 256-263. [CrossRef]

3. Li, K.; Xiao, B. Research on Combustion Strategy of Diesel/Natural Gas Dual Fuel Engine. Chin. Intern. Combust. Engine Eng. 2017, 38, 24-29.

4. Wang, Z.; Zhao, Z.; Wang, D.; Wang, D.; Tan, M.; Han, Y.; Liu, Z.; Dou, H. Impact of pilot diesel ignition mode on combustion and emissions characteristics of a diesel/natural gas dual fuel heavy-duty engine. Fuel 2016, 167, 248-256. [CrossRef] 
5. Chatlatanagulchai, W.; Yaovaja, K.; Rhienprayoon, S.; Wannatong, K. Air-fuel ratio regulation with optimum throttle opening in diesel-dual-fuel engine. SAE Tech. Pap. 2010. [CrossRef]

6. Fu, Y.; Xiao, B.; Zhang, C.; Liu, J.; Fang, J. A new method for on-line estimation of the piston maximum temperature in diesel-nature gas dual fuel engine. J. Eng. Gas Turbines Power 2018, 140, 061507. [CrossRef]

7. Pedrozo, V.B.; May, I.; Lanzanova, T.D.M.; Zhao, H. Potential of internal EGR and throttled operation for low load extension of ethanol-diesel dual-fuel reactivity controlled compression ignition combustion on a heavy-duty engine. Fuel 2016, 179, 391-405. [CrossRef]

8. Henham, A.; Makkar, M.K. Combustion of simulated biogas in a dual-fuel diesel engine. Energy Convers. Manag. 1998, 39, 2001-2009. [CrossRef]

9. Peng, Y.H.; Huang, Y.P.; Tang, J.Y.; Huang, Q.F.; Huang, Y.R. Experimental study on the effects of air supply control on combustion and emissions performance at medium and low load for a dual-fuel diesel engine. Energies 2018, 11, 2944. [CrossRef]

10. Belgiorno, G.; Di, B.G.; Beatrice, C. Parametric study and optimization of the main engine calibration parameters and compression ratio of a methane-diesel dual fuel engine. Fuel 2018, 222, 821-840. [CrossRef]

11. Yang, B.; Xi, C.X.; Wei, X.; Zeng, K.; Lai, M.C. Parametric investigation of natural gas port injection and diesel pilot injection on the combustion and emissions of a turbo-charged common rail dual-fuel engine at low load. Appl. Energy 2015, 143, 130-137. [CrossRef]

12. Meng, L.; Zhang, C.H.; Bao, X.F.; Song, J.Y.; Liu, Z.M. Effects of the substitution rate of natural gas on the combustion and emission characteristics in a dual-fuel engine under full load. Adv. Mech. Eng. 2017, 9, 1-8.

13. Hutter, R.; Ritzmann, J.; Elbert, P.; Onder, C. Low-Load Limit in a Diesel-Ignited Gas Engine. Energies 2017, 10, 1450. [CrossRef]

14. Yousefi, A.; Gou, H.S.; Birouk, M. Effect of diesel injection timing on the combustion of natural gas/diesel dual-fuel engine at low-high load and low-high speed conditions. Fuel 2019, 235, 838-846. [CrossRef]

15. Yousefi, A.; Gou, H.S.; Birouk, M. Effect of swirl ratio on NG/diesel dual-fuel combustion at low to high engine load conditions. Appl. Energy 2018, 229, 375-388. [CrossRef]

16. Peng, Y.H.; Wu, Z.Z.; Chen, X.Z.; Huang, Y.R. Real-time metering method for dynamic flow of natural gas injector. Chin. J. Sci. Instrum. 2018, 39, 11-17.

17. Ministry of Ecology and Environment of RPC. GB 20891-2014; Limits and Measurement Methods for Exhaust Pollutants from Diesel Engines of Non-Road Mobile Machinery (CHINA III, IV); China Environmental Science Press: Beijing, China, 2014.

18. Yousefi, A.; Guo, H.S.; Birouk, M. An experimental and numerical study on diesel injection split of a natural gas/diesel dual-fuel engine at a low engine load. Fuel 2018, 212, 332-346. [CrossRef]

19. Wang, J.X.; Shuai, S.J. Automotive Engine Fundamentals; Tsinghua University Press: Beijing, China, 2011.

20. Liu, J.; Yang, F.; Wang, H.; Ouyang, M.; Hao, S. Effects of pilot fuel quantity on the emissions characteristics of a CNG/diesel dual fuel engine with optimized pilot injection timing. Appl. Energy 2013, 110, 201-206. [CrossRef]

21. Jiaqiang, E.; Pham, M.H.; Deng, Y.; Nguyen, T.; Duy, V.; Le, D.; Zuo, W.; Peng, Q.; Zhang, Z. Effects of injection timing and injection pressure on performance and exhaust emissions of a common rail diesel engine fueled by various concentrations of fish-oil biodiesel blends. Energy 2018, 149, 979-989.

22. Lopez, J.M.; Gomez, A.; Aparicio, F.; Javier Sanchez, F. Comparison of GHG emissions from diesel, biodiesel and natural gas refuse trucks of the city of madrid. Appl. Energy 2009, 86, 610-615. [CrossRef]

23. Papagiannakis, R.G.; Hountalas, D.T. Combustion and exhaust emission characteristics of a dual fuel compression ignition engine operated with pilot diesel fuel and natural gas. Energy Convers. Manag. 2004, 45, 2971-2987. [CrossRef]

24. Papagiannakis, R.G.; Rakopoulos, C.D.; Hountalas, D.T. Emission characteristics of high speed, dual fuel, compression ignition engine operating in a wide range of natural gas/diesel fuel proportions. Fuel 2010, 89, 1397-1406. [CrossRef]

25. Maxey, C.; Kalaskar, V.; Kang, D.; Boehman, A. Impact of supplemental natural gas on engine efficiency, performance, and emissions. SAE Tech. Pap. 2013. [CrossRef]

26. Wei, L.; Geng, P. A review on natural gas/diesel dual fuel combustion, emissions and performance. Fuel Process. Technol. 2016, 142, 264-278. [CrossRef] 
27. Singh, S.; Krishnan, S.R.; Srinivasan, K.K.; Midkiff, K.C.; Bell, S.R. Effect of pilot injection timing pilot quantity and intake charge conditions on performance and emissions for an advanced low-pilot-ignited natural gas engine. Int. J. Engine Res. 2004, 5, 329-348. [CrossRef]

28. Cameretti, M.C.; Tuccillo, R.; De Simio, L.; Iannaccone, S.; Ciaravola, U. A numercal and experimental study of dual fuel diesel engine for different injection timings. Appl. Therm. Eng. 2016, 101, 630-638. [CrossRef]

29. Papagiannakis, R.G.; Hountalas, D.T.; Krishnan, S.R.; Srinivasan, K.K.; Rakopoulos, D.C. Numerical Evaluation of the Effects of Compression Ratio and Diesel Fuel Injection Timing on the Performance and Emissions of a Fumigated Natural Gas-Diesel Dual-Fuel Engine. J. Energy Eng. 2016, 142. [CrossRef]

(C) 2019 by the authors. Licensee MDPI, Basel, Switzerland. This article is an open access article distributed under the terms and conditions of the Creative Commons Attribution (CC BY) license (http://creativecommons.org/licenses/by/4.0/). 